\title{
¿Verdad o belleza? Pintura, fotografía, memoria, historia
}

\begin{abstract}
Laura Malosetti Costa*
\section{Resumen:}

En el marco de una investigación en curso sobre la obra de José Gil de Castro (Lima, 1785-1837), un artista que retrató a los líderes revolucionarios americanos (José de San Martín, Simón Bolívar, Bernardo O’Higgins, entre otros) este ensayo propone una indagación sobre la función y fortuna crítica de los retratos pintados de los héroes y protagonistas de las historias nacionales, antes y después de la invención de la fotografía. Cuáles se vuelven lugares de la memoria colectiva y cuáles no, cómo se activa y desactiva la eficacia simbólica de las diferentes representaciones de un rostro a lo largo del tiempo, son algunas de las cuestiones abordadas.
\end{abstract}

\section{Palabras clave:}

Imágenes canónicas; fotografía; memoria

En la fotografía el valor de exhibición empieza a hacer retroceder al máximo el valor de culto. Pero éste no cede sin resistencia. Ocupa una última

trinchera que es el rostro humano.[...].

En las primeras fotografías el aura nos hace señales por vez postrera en la expresión fugaz de un rostro humano.

Y eso es lo que constituye su belleza melancólica e incomparable. Walter Benjamin ${ }^{1}$

\section{I}

En este texto quisiera plantear algunas cuestiones a propósito de los retratos de los llamados "héroes" o "próceres" de las naciones latinoamericanas, a partir de una investigación en curso de la que formo parte y que involucra a varias de ellas. ${ }^{2}$ Cuestiones sobre el parecido y el efecto de presencia, sobre las funciones y

\footnotetext{
* Crítica de arte, profesora del Instituto de Altos Estudios Sociales - Universidad Nacional de San Martín e investigadora del CONICET, Argentina.

1 "La obra de arte en la época de su reproductibilidad técnica" (versión de 1939) en Walter Benjamin (2004, p. 98 y p. 106-107).
} 
usos del retrato, y - en el caso particular de los retratos de esos personajes - los modos y mecanismos según los cuales llegaron algunos de ellos a ser lugares de memoria colectiva y de construcción de ideas y sentimientos acerca de la historia. Cómo interactuaron e interactúan esos retratos con tales ideas y sentimientos antes y después de la fijación de relatos historiográficos hegemónicos, pero también antes y después de la invención de la fotografía, son las cuestiones que quisiera abordar aquí a partir del análisis de algunos ejemplos.

La hipótesis es que en el caso particular de la construcción de imágenes canónicas de los héroes, tras una aparente preocupación iconográfica por encontrar - y divulgar - la "vera efigie" de aquellos, el criterio que primó fue la reconstrucción ideal de su apariencia, siguiendo criterios de forma y estilo que se ajustaron más a consideraciones de índole moral y política, así como su adecuación a la función que debían cumplir.

Pero además -y sigo aquí a Louis Marin- algunos de estos retratos, cuya presencia y memoria se sostiene a partir del discurso historiográfico, parecen desbordarlo. Atravesadas por la palabra, ciertas imágenes atraviesan a su vez el discurso y lo transforman. ${ }^{3}$ Y probablemente algo en esos retratos -rostros, uniformes, miradas- calen más hondo en la psique de sucesivas generaciones de ciudadanos que la abstracción simplificada y estereotipada de los relatos históricos, memorizados un poco mecánicamente, en la escuela primaria.

Algunos guerreros de la Independencia vivieron lo suficiente como para poder ser fotografiados. La comparación de los daguerrotipos que se conservan en el Museo Histórico Nacional de Buenos Aires con los retratos al óleo de esos mismos personajes retratados por José Gil de Castro en los años de la guerra emancipadora aparece en el cruce de la différance derrideana. Diferencia que es diferimiento, respecto de los retratos al óleo que muestran a aquellos jóvenes guerreros en sus años juveniles, vistiendo uniformes y luciendo sus primeras medallas, pero también una imposibilidad del aquí y ahora en la trama de fugacidades atrapada en la imagen. $Y$ a partir de esa diferencia y diferimiento del efecto de presencia en la imagen quisiera abordar toda una serie de pares de retratos, separados entre sí por el tiempo y la técnica, pero sobre todo por sus sucesivos usos y apropiaciones a lo largo del tiempo.

Es en el entramado de estas cuestiones que propongo considerar algunos retratos inmensamente populares junto a otros que aparecen como incrustados en su tiempo y lugar, atrapados en una trama de convenciones que nos son hoy, en

\footnotetext{
2 Este trabajo ha sido realizado en el marco del proyecto "JOSÉ GIL DE CASTRO: CULTURA VISUAL Y REPRESENTACIÓN, DEL ANTIGUO RÉGIMEN A LAS REPÚBLICAS SUDAMERICANAS" dirigido por la Dra. Natalia Majluf, Directora del Museo de Arte de Lima, y financiado por la J. Paul Getty Foundation. Agradezco al Director del Museo Histórico Nacional (MHN) de Buenos Aires, Dr. José Antonio Pérez Gollán, al Jefe de Investigación del mismo, Lic. Miguel Ruffo, muy especialmente a la Lic. Viviana Isola, a cargo del departamento de documentación, a la Lic. Sofía Oguic, a cargo del archivo histórico, a Vilma Pérez Casalet, jefa de conservación y a Diego Alberto Ruiz, bibliotecario de dicha institución, por la invalorable y desinteresada colaboración que me han brindado en el curso de esta investigación. Juan Manuel Martínez, curador en jefe del Museo Histórico Nacional de Chile, ha sido, como siempre, mi más atento interlocutor en Santiago.
}

${ }^{3}$ Louis Marin, Des pouvoirs de l'image. Gloses (1993). 
buena medida, ajenas. Desnaturalizando su función mimética evidente, la propuesta es trabajar sobre la opacidad de esos retratos, de aquello que nos dicen de sí mismos conjurados por la palabra y la mirada actual, restituyéndolos luego a la trama de la historia que los hizo posibles y los sostiene en algún lugar de nuestra cultura.

El daguerrotipo aparece anclado en un momento preciso, en el que el dispositivo fotográfico irrumpía con enorme fuerza en el campo de actividad de los retratistas, pero sobre todo de los miniaturistas. El retrato no fue considerado entre los géneros "mayores" de la pintura dentro de las jerarquías académicas, en tanto la exigencia del parecido restringía al máximo las posibilidades de invención de los pintores. En el retrato, aquéllos debían ser, ante todo, fieles a la naturaleza, ya que la imagen debía hablar a los sentidos antes que a la inteligencia: la definición última del retrato era (es) el reconocimiento de un individuo, su evocación por medios visuales. ${ }^{4} \mathrm{Y}$ si bien no siempre fue el parecido el parámetro de tal evocación, sí lo fue, indudablemente, en el siglo XIX, cuando el deseo de capturar una "verdad" y sus fantasmas en la imagen dio por resultado una proliferación de invenciones técnicas para lograrlo. ${ }^{5}$

De modo que no fue tanto la creatividad del artista sino más bien su habilidad para lograr la semejanza con el modelo aquello que se valoró más en relación con el retrato, pero sobre todo con los usos privados del género. Es decir: en aquellos retratos en los que, más allá o más acá de los símbolos exteriores desplegados en las ropas o accesorios que las enmarcan y connotan, efectivamente, lo esencial era el parecido en las facciones, condición ineludible para lograr ser soporte de la vanidad o del recuerdo de los seres queridos y sobre todo de los muertos.

En este sentido, Aaron Scharf señala que "el primer grupo de artistas que sufrió los efectos de la fotografía fue el de los retratistas en miniatura", cosa que demuestra con la paulatina desaparición del Miniature Room en las sucesivas exposiciones de la Royal Academy de Londres a lo largo del siglo. ${ }^{6}$ Casi enseguida los miniaturistas encontraron una nueva ocupación coloreando daguerrotipos y pintando miniaturas sobre la imagen daguerreana, cuando no encararon la nueva técnica ellos mismos.

Estas consideraciones nos llevan a uno de los asuntos más interesantes y menos atendidos del retrato: la complicidad, la necesaria transacción entre el retratado y el retratista en la construcción de la imagen, una cuestión que involucra tanto a los retratos pintados como a los fotográficos. ${ }^{7}$ La pose, el vestido, la puesta en escena como un espacio de negociación, en un tiempo y un espacio entre ambos que se inscribe a su vez en un momento histórico preciso. Desde allí, la imagen nos mira, se vuelve anacrónica desde su particular

\footnotetext{
${ }^{4}$ Ludmilla Jordanova, Defining features. Scientific and medical portraits 1660-2000 (2000, p. 13-20).

${ }^{5}$ Geoffrey Batchen, Arder en deseo. La concepción de la fotografía (2004 passim).

${ }^{6}$ Aaron Scharf, Art and Photography (1974, p. 42-44).

7 Marcia Pointon, Hanging the head. Portraiture and Social Formation in Eighteenth-Century England (1993).
} 
anclaje en una constelación de significados. ${ }^{8}$

\section{II}

Esta cuestión de la distancia entre la fotografía y la pintura en momentos en que fue urgente la producción de retratos en las naciones latinoamericanas que estaban luchando por independizarse de España, es un tema que vengo investigando en el marco del proyecto "José Gil de Castro", en relación con la fortuna crítica y la deriva histórica de los retratos pintados por aquel mulato peruano. Formado en los talleres de pintura colonial de Lima, activo en Chile al menos desde 1814, Gil de Castro se volvió el retratista de moda de la sociedad santiaguina y, desde el triunfo del Ejército de los Andes comandado por José de San Martín en la batalla de Chacabuco, el retratista de sus generales y altos oficiales, proto-antigraphista, cosmógrafo y topógrafo del ejército libertador. Entre 1817 y 1821 retrató a casi todos los oficiales de la plana mayor del ejército y luego volvió con éste a Lima donde realizó algunos de los retratos más difundidos de Simón Bolívar, y donde murió en 1837. Hernán Rodríguez Villegas, historiador de la fotografía en Chile, sostiene la hipótesis de que Gil de Castro hubiera utilizado en Chile la cámara oscura para la realización de sus retratos, basando su suposición en el hecho de que eligió siempre el perfil de tres cuartos para la pose de sus modelos, a los efectos de lograr su individualización de sus rasgos. ${ }^{9}$

Aun cuando nunca estuvo Gil de Castro en Buenos Aires, se conservan allí en colecciones públicas 29 retratos, de los cuales 26 están en el Museo Histórico Nacional. Casi todos ellos fueron solicitados por su primer director, Adolfo P. Carranza, y donados por los familiares y herederos de los retratados en los primeros años de existencia del Museo.

Este grupo de retratos es notablemente homogéneo, repitiendo una fórmula con ligeras variantes según -evidentemente- una cierta negociación con el retratado y la función -pública o privada- del cuadro. Es de notar la diferencia entre los retratos de San Martín y de Bernardo O Higgins, y más tarde los de Simón Bolívar, y los de sus oficiales, retratados con todas sus medallas, uniformes, charreteras, espadas, pero destinados casi todos ellos a un uso privado, tal vez preservar su recuerdo ante la eventualidad de morir en combate. Así lo hacen suponer las inscripciones que a veces se encuentran en la imagen acompañando al retratado: dedicatorias a la madre, la esposa, la hermana, los hijos o, como en el caso del retrato del coronel José Antonio Melián -vestido de civil-, palabras que, con el valor de una declaración de principios, están dirigidas al uniforme que descansa a su lado: "Volveré a vestirte y esgrimiré mi sable toda vez que los enemigos de mi patria atenten contra ella" [FIGURA 1]. Pintados casi todos ellos en Chile, fueron llevados a la Argentina en su mayoría por los mismos retratados. Su deterioro nos hace suponer que enrollados, a lomo de mula, a través de la cordillera.

\footnotetext{
${ }^{8}$ Georges Didi-Huberman, Ante el tiempo. Historia del arte y anacronismo (2006 passim). 


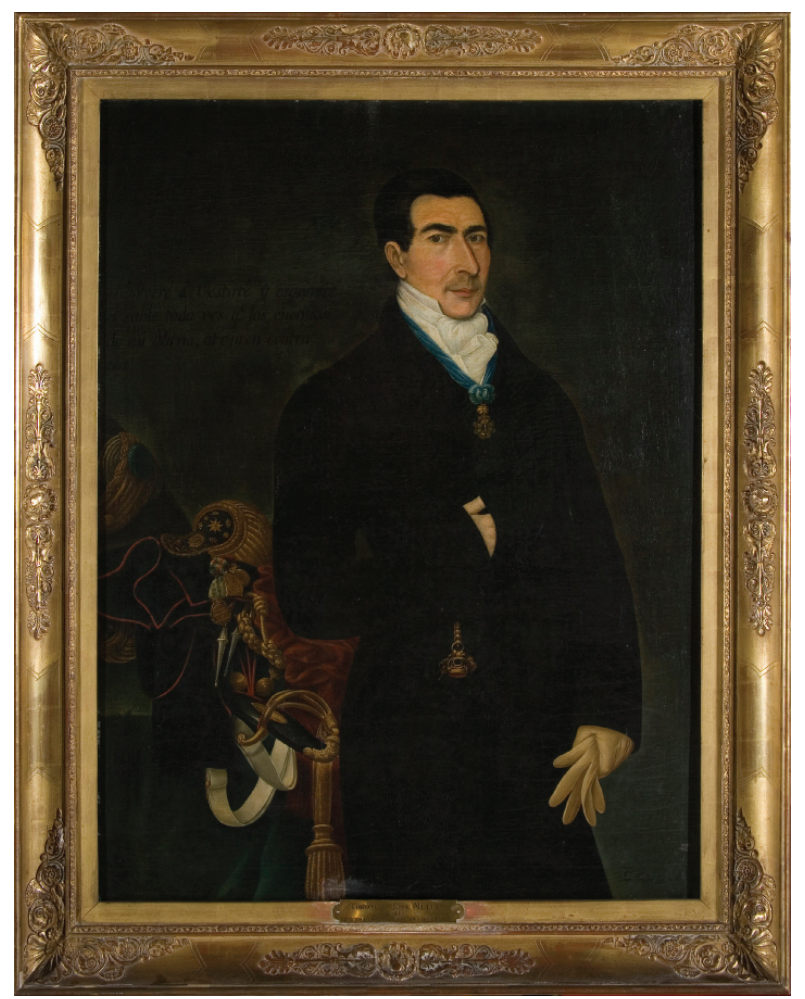

FIGURA 1 - José Gil de Castro, Coronel José Antonio Melián, 1819, óleo sobre tela, 123 x 97,5 cm. MHN Buenos Aires

¿Cómo definir el conjunto? Tal vez como tradicionalmente se les ha llamado: guerreros de la independencia. Es decir, un grupo que se definió iconográficamente como de hombres de guerra, con toda la parafernalia simbólica que distingue ese particular subgénero del retrato: uniformes, medallas, sombreros, un tipo especial de empaque, y una gestualidad que, en el caso de los retratos de Gil de Castro, deriva de la retratística de los virreyes en América, y en otros de la retórica revolucionaria francesa y la iconografía napoleónica. Son ellos los que la historiografía ha consagrado como héroes o padres de la patria en Argentina, Chile, Perú, Bolivia, Venezuela, Uruguay, Colombia.

Las guerras de la independencia latinoamericana tuvieron lugar unos veinte años antes de la invención de la fotografía. En el fragor de las campañas militares sus líderes fueron retratados, casi con urgencia. A la vez que se creaba toda una nueva iconografía republicana, se hacía necesario sustituir la imagen del rey y de los virreyes por un nuevo panteón de héroes y de líderes revolucionarios. La invención de la fotografía, cuya fascinante historia de simultaneidad nos habla de ese "ardiente deseo" (en palabras de Daguerre, evocadas por Geoffrey Batchen) de capturar aquello que se pensó como la mano de la naturaleza -o de dios- en la elaboración de las imágenes llegó a esta región cuando aquellos héroes ya habían muerto o eran ancianos. Algunos de ellos posaron para la cámara, a veces enfundados en sus viejos uniformes, cargados de medallas. El impacto que produce la comparación de esos daguerrotipos con los retratos pintados por Gil de Castro cuando se encontraban de campaña en Chile nos pone ante la cuestión que planteaba al principio: hay una discontinuidad radical entre esos retratos, 
una desconexión, un hiato entre la idea del héroe y su imagen captada por el daguerrotipo.

El daguerrotipo de San Martín, sin embargo, aun cuando fue tomado en 1848, cuando éste tenía más de 70 años, fue una de las imágenes más difundidas del prócer [FIGURA 2]. En la misma sesión fueron tomados dos daguerrotipos casi iguales, uno de los cuales (de paradero desconocido) fue grabado por el artista francés Edmond Castan. ${ }^{10}$ El otro daguerrotipo, que se conserva en el MHN, fue donado por José Prudencio de Guerrico el 22 de abril de 1900.11 Fue esa imagen de San Martín la que se utilizó en sucesivas emisiones de papel moneda y en estampillas postales. En el texto escrito para el sitio oficial del Instituto Nacional Sanmartiniano, Enrique M. Mayochi escribe: "Los daguerrotipos de 1848 son, en rigor, los únicos retratos verdaderamente directos del general San Martín. Es una fortuna que el progreso de la técnica haya permitido hacer llegar hasta nosotros su imagen de esta indubitable manera". ${ }^{12}$

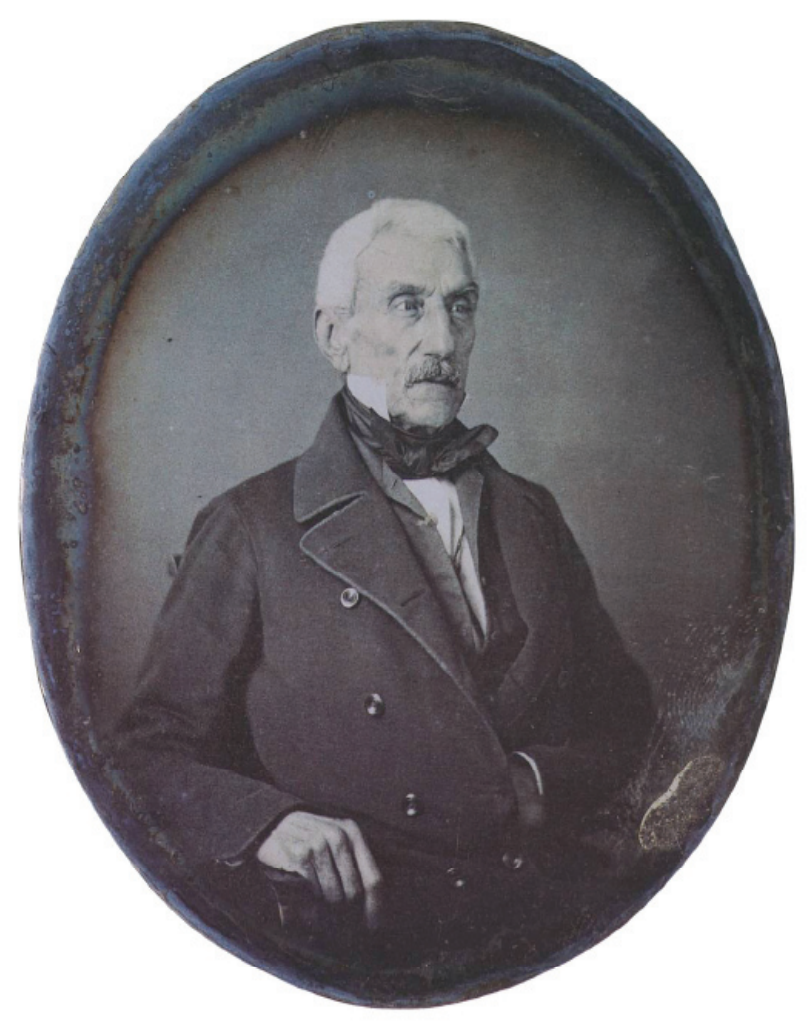

FIGURA 2 - Autor no identificado, General José de San Martín, 1848, París, daguerrotipo 12 x $10 \mathrm{~cm}$. MHN Buenos Aires

10 Cfr. A.A.V.V., Los años del daguerrotipo. Primeras fotografías argentinas $1843-1870$ (1995, p. 2425). Este fue la fuente iconográfica para el grabado realizado por Desmadryl en 1857 para la Galería de Celebridades Argentinas, comentado y elogiado en la semblanza del héroe escrita por Sarmiento para acompañar dicha entrega. Cfr. Roberto Amigo, "Imágenes de la historia y discurso político en el Estado de Buenos Aires (1852-1862) - I. La Galería de los Héroes" en Arte Argentino de los Siglos XVIII y/o XIX. Menciones especiales Premio Telefónica a la Investigación en Historia de las Artes Plásticas (1998, p. 18-19).

${ }^{11}$ Cfr. Catálogo MHN p. 204, No 1644 (Obj. No 1315).

12 www.sanmartiniano.gov.ar/textos/parte3/texto097.php 
Sin embargo no es ésa ni tampoco la de Gil de Castro la imagen más difundida de José de San Martín.

En este sentido conviene aquí una breve reflexión acerca del papel del Museo Histórico Nacional (MHN) fundado en Buenos Aires en 1889 en la selección y difusión de las imágenes de los héroes.

Fruto de un modelo historiográfico orientado a formar una "tradición nacional" armoniosa, organizado alrededor de los "grandes hombres" de Mayo y las guerras de emancipación, que servirían de ejemplo y guía a las generaciones futuras, ${ }^{13}$ el Museo Histórico fundado en 1889 tuvo una clara función pedagógica. Los retratos, armas, uniformes y otras reliquias de aquellas gestas impresionarían la imaginación de los ciudadanos -y en particular los niños- sembrando en ellos sentimientos patrióticos. En este sentido, se organizó alrededor del carácter casi sagrado de su patrimonio. El MHN fue ante todo una colección venerable, un relicario, un templo de la patria y, en particular, de su ejército. ${ }^{14}$ Pero el museo funcionó también como promotor de homenajes, repatriaciones de restos, desfiles, apoteosis, suscripciones para erigir monumentos, además de numerosas publicaciones que difundieron imágenes de su patrimonio, a medida que éste se iba incrementando con un aluvión de donaciones. ${ }^{15}$

La presencia de los héroes de la independencia en el museo se haría efectiva en las reliquias auténticas que éste atesorara: los uniformes que vistieron en las batallas, las medallas que recibieron, sus armas, sus pertenencias personales, etc. Pero aquel efecto de presencia sin duda no sería eficaz si los visitantes no podían ver el rostro de aquellos "grandes hombres". De ahí la insistencia con que su fundador, Adolfo P. Carranza, pidió a las familias "buenos retratos" de sus antepasados ilustres, originales, auténticos. Los primeros retratos de José de San Martín y sus oficiales que ingresaron al patrimonio del MHN fueron los retratos de José Gil de Castro, y en las primeras publicaciones éstos -y en particular el de San Martín- fueron reproducidos por miles.

Las fotografías que se conservan de la disposición del MHN en sus primeros años muestra un abigarramiento en el que parece haber resultado difícil orientarse. Por eso, más allá de la exhibición en sus salas, es probable que hayan sido otros aspectos de la actividad del MHN los que más contribuyeron a difundir los retratos de los próceres. La reproducción de esos retratos en láminas sueltas, la publicación de folletos y libros ilustrados, el asesoramiento a directores de escuela, mu-

\footnotetext{
13 Así quedaba expresado en el primer párrafo del decreto de fundación del Museo Histórico de la Capital (24 de mayo de 1889): "Considerando que el mantenimiento de las tradiciones de la Revolución de Mayo y de la guerra de la Independencia, es de trascendental interés nacional y que concurriendo a ese fin los monumentos y otros objetos que pertenecen a aquella gran época, deben ser respetados, y conservados" etc. Libro de Notas I (en adelante LN I) Museo Histórico de la Capital, f. 3.

${ }^{14}$ En el año 1897 Ernesto Quesada escribió un folleto en ocasión de la inauguración de una nueva sede (la actual) para el MHN. Allí observaba que: "La faz civil de nuestra historia durante el período de la guerra de independencia, es más pobre en el museo que la faz militar." El Museo Histórico Nacional y su importancia patriótica - con motivo de la inauguración del nuevo local en el Parque Lezama. Buenos Aires, Kraft, 1897, p. 22

15 Ernesto Quesada escribe en 1897 que "comenzó con 191 objetos: el último catálogo le asigna 1240 y hoy probablemente tendrá más de 1500". Las donaciones fueron en su mayoría reliquias y retratos de la época de la independencia. Op. cit. p. 6.
} 
seos provinciales, escultores y pintores que realizaron copias, etc., ubica a Adolfo P. Carrranza y a los sucesivos directores del MHN como verdaderos árbitros de la valoración y circulación de las imágenes de su patrimonio. En un primer momento, y hasta que no ingresaron a su acervo retratos considerados "mejores", los óleos de Gil de Castro tuvieron amplia difusión.

En 1897 el MHN ya tenía varios retratos de San Martín, pero en 1899 ingresó a su patrimonio uno que inmediatamente fue adoptado y difundido como la imagen canónica del héroe. Es un retrato anónimo, atribuido a una maestra de dibujo de la hija del prócer, Merceditas San Martín, pintado en Bruselas en los primeros años de su ostracismo. Bastante antes de su donación al MHN fue considerado "el mejor" retrato del general por quienes lo conocieron. Fue la fuente iconográfica del monumento levantado a San Martín en Buenos Aires en $1862 .{ }^{16}$ Compuesto con el modelo evidente del retrato de Napoleón en el Puente de Arcole de Jean Antoine Gros, ha sido Ilamado "el retrato de la bandera". Ese retrato ingresó al MHN como parte del dormitorio del general retirado en su casa de Boulogne Sur Mer. Su nieta, Josefa Balcarce y San Martín de Gutiérrez de Estrada donó todo cuanto había en ese dormitorio, con el agregado de un croquis que explicaba cómo debía ubicarse cada cosa para que fuera reconstruido fielmente en las salas del museo.

Su ubicación en el dormitorio de San Martín daba a ese cuadro un carácter especial: el propio general lo había privilegiado respecto de todos los demás retratos suyos, al ser el único que conservaba en su dormitorio, entre un retrato de Napoleón y otro de Wellington, ambos en grabado. Sin duda, más allá de las connotaciones políticas que ello pueda implicar, San Martín (o tal vez su hija y su nieta) parece haber tenido una clara preferencia por el modelo iconográfico napoleónico. Los retratos de Gil de Castro tenían una estética tardocolonial poco apropiada a sus propias ideas acerca de cómo debía lucir su imagen como libertador americano.

A partir de su ingreso al MHN, su ubicación destacada en el dormitorio y el privilegio de que gozó de ahí en más en las publicaciones del museo, el "retrato de la bandera" quedó instalado, decididamente, en primer lugar en la construcción de la imagen del héroe. ${ }^{17}$

Las consideraciones de Bartolomé Mitre, en relación con los retratos de San Martín, aparecen, claramente, como inspiradoras de la inmediata aceptación de este

\footnotetext{
${ }^{16}$ En el libro dedicado a la erección del monumento, publicado en 1863 , se comenta la iconografía elegida para la realización del rostro de la estatua: "Retrato al óleo del general San Martín hecho por una señora de Bruxelas, que fue una de las institutrices de la señora doña Mercedes San Martín de Balcarce. El general está representado con la bandera argentina en la mano, cuyos colores sirven de fondo al cuadro. Este cuadro pertenece a la familia del general, y era el más estimado por el personaje que representa. Ha servido para modelar la cabeza de las estatuas erigidas en Buenos Aires y en Santiago de Chile". El general San Martín. Buenos Aires: Imprenta del Comercio del Plata, 1863, p. 352.

17 Sería imposible detallar el número de sus reproducciones en álbumes y figuritas escolares, revistas, libros de texto, láminas para las oficinas públicas, etc., de este retrato. En 1910, para el centenario de la revolución de mayo, fue objeto de miles de reproducciones en abanicos, souvenirs, estampas, postales, etc. Valga sólo a modo de ejemplo que en 2009, es ése el retrato de San Martín que la Presidenta argentina eligió para ser ubicado en el salón que estará dedicado al Bicentenario en la Casa Rosada.
} 
retrato como imagen canónica en relación con su gran relato historiográfico, aquél que había fijado la semblanza del héroe. En la primera edición de su Historia de San Martín, de 1878, Bartolomé Mitre reprodujo en las tapas de los tres tomos la silueta del monumento y éste ocupó la portadilla del primero. ${ }^{18}$ En el prólogo explicó las imágenes que había incluido en el texto (cinco) señalando cada una de ellas como la cabeza de serie de las restantes 25 que conocía. La de Bruselas también había sido señalada por él como "la preferida del general", la que había sido usada como fuente para el rostro del monumento y -a su criterio- la mejor:

Tiene la expresión ideal y heroica, reveladora del temple de su alma, que ha sido trasportada al bronce al modelar las cabezas de sus estatuas de Santiago de Chile y de Buenos Aires, cuyos rostros constituyen la parte más acabada y más notable de esta obra, así por su ejecución como por su expresión. Este retrato es el que San Martín prefería, y ha sido conservado en su familia. Distínguese por llevar en la mano una bandera celeste y blanca, cuyos pliegues forman el fondo del cuadro. ${ }^{19}$

Mitre consideró los retratos de Gil de Castro como testimonios "fieles" de una época precisa, la de la emancipación, y del empaque viril de aquellos soldados. Pero el retrato "de Bruselas" se ajustaba mucho mejor a una reconstrucción ideal del "alma" del héroe, tal como su relato historiográfico requería y como debía leerse en su rostro. Respondía, sin duda, a una estética "moderna", romántica, envuelto a la manera de un Napoleón en la bandera argentina, mirando hacia un punto alto, como si reflexionara acerca de un mejor destino para su patria. El retrato "de la maestra de Merceditas" se acercaba más a los cánones del final del siglo XIX que la figura un poco envarada, frontal y ornamentada, con un fuerte aire tardocolonial, de Gil de Castro [FIGURAS 3 e 4]. Además de ser también "auténtico" (se decía que San Martín había posado para esa maestra anónima), el retrato "de la bandera" había sido atesorado por él en tanto que se había desprendido de todos los de Gil. La primera autoridad invocada en términos de preferencias estéticas, entonces, fue el mismo San Martín.

Ha sido una verdadera obsesión de historiadores, directores del MHN e iconógrafos (en particular del ejército y del Instituto Nacional Sanmartiniano) establecer la "vera efigie" de San Martín, lo cual dio lugar a toda clase de estudios, interpretaciones y discusiones que tienen como punto de partida, como vimos, la decisión en cuanto a qué rostro debía tener la estatua encargada a Daumas y que se continuó en diversas composiciones de sus rasgos a partir de los "tipos" existentes, entre ellos el de Gil. ${ }^{20}$ Existiendo un daguerrotipo, a primera vista aquél debería haber zanjado la cuestión. Pero el problema es que había sido tomado cuando el

\footnotetext{
${ }^{18}$ Bartolomé Mitre, Historia de San Martín y de la emancipación sud-americana (1887).

${ }^{19}$ Ibid. p. 18. Mitre distinguía cinco retratos "auténticos". El último de ellos, claro, era el daguerrotipo, sin duda el más "verdadero" pero también el que menos representaba su fase heroica, no obstante lo cual había sido el elegido para hacer estampillas y billetes de banco. 


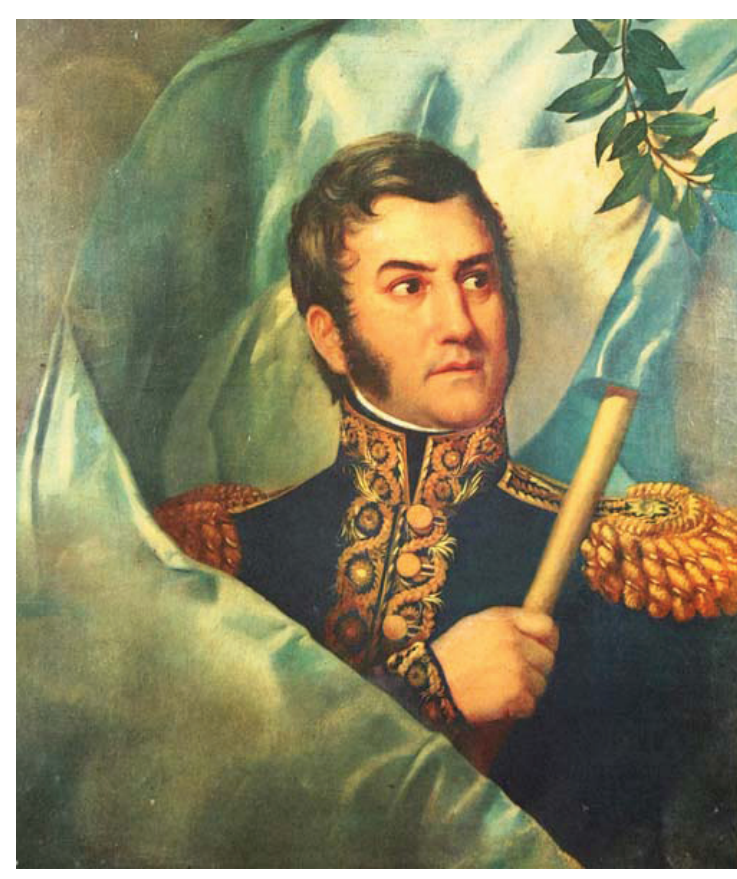

FIGURA 3 - Retrato de San Martin Autor anônimo

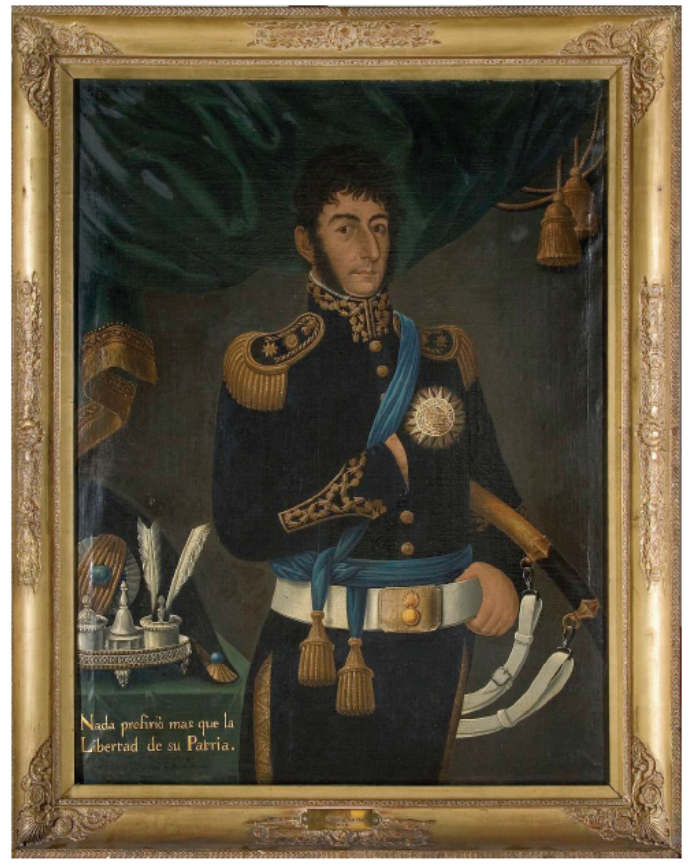

FIGURA 4 - José Gil de Castro, General José de San Martín, 1818, óleo sobre tela $111 \times 83,5$, MHN Buenos Aires

general estaba viejo, a los 71 años, y no fue una imagen que pudiera evocar idealmente al guerrero del ejército de los Andes. Reconstrucciones ideales y "rejuvenecimientos" de la imagen daguerreana dieron lugar a retratos como los de Rafael del Villar en los años treinta, un poco más tarde a los de Pablo Ducros Hicken y recientemente al de Guillermo Roux, entre muchos otros. ${ }^{21}$ Pero fue en los billetes de banco, en las monedas y estampillas de correo, donde la imagen "venerable" de San Martín anciano tuvo lugar: un lugar de garante de la confiabilidad del estado. Para esta función el viejo y reposado San Martín, muerto serenamente en el ostracismo, ejemplo de sobriedad y padre ejemplar, resultaba inmejorable. Los retratos de Gil de Castro, salvo excepciones señaladas claramente por su uso castrense, cayeron prácticamente en el olvido. ${ }^{22}$

¿Qué ocurrió con los retratos de los oficiales de San Martín, los otros generales del ejército libertador? En algunos casos la única imagen disponible fue la de los retratos de Gil de Castro, pero en otros no. El MHN recibió tempranamente varios daguerrotipos de aquellos guerreros de la independencia: Tomás Guido, Gregorio de Las Heras, Ignacio Alvarez Thomas entre ellos. Pero son imágenes muy poco conocidas y difundidas. El de Alvarez Thomas, por ejemplo, lo presenta anciano y enfundado en su viejo uniforme, que ostensiblemente le va pequeño y al que falta un botón [FIGURA 5]. Las Heras posa en una rígida actitud militar ya muy entrado en años, lo cual da a la imagen un anacronismo aún más evidente. El daguerro-

\footnotetext{
${ }^{21}$ Puede consultarse la pinacoteca virtual sanmartiniana, realizada por L. Estol para el Instituto Nacional Sanmartiniano en: http://www.sanmartiniano.gov.ar/multimedia/pinacotecavirtual.php
} 
tipo de Tomás Guido (Buenos Aires, 1788-1866) es el de un anciano vestido de civil, con abrigo y bastón, sentado a una mesa [FIGURA 6]. Sin duda su larga carrera política se hace evidente en este retrato maduro. ${ }^{23}$ Nada más distante del joven y elegante guerrero de los Andes que aparece en el retrato de Gil de Castro [FIGURA 7].

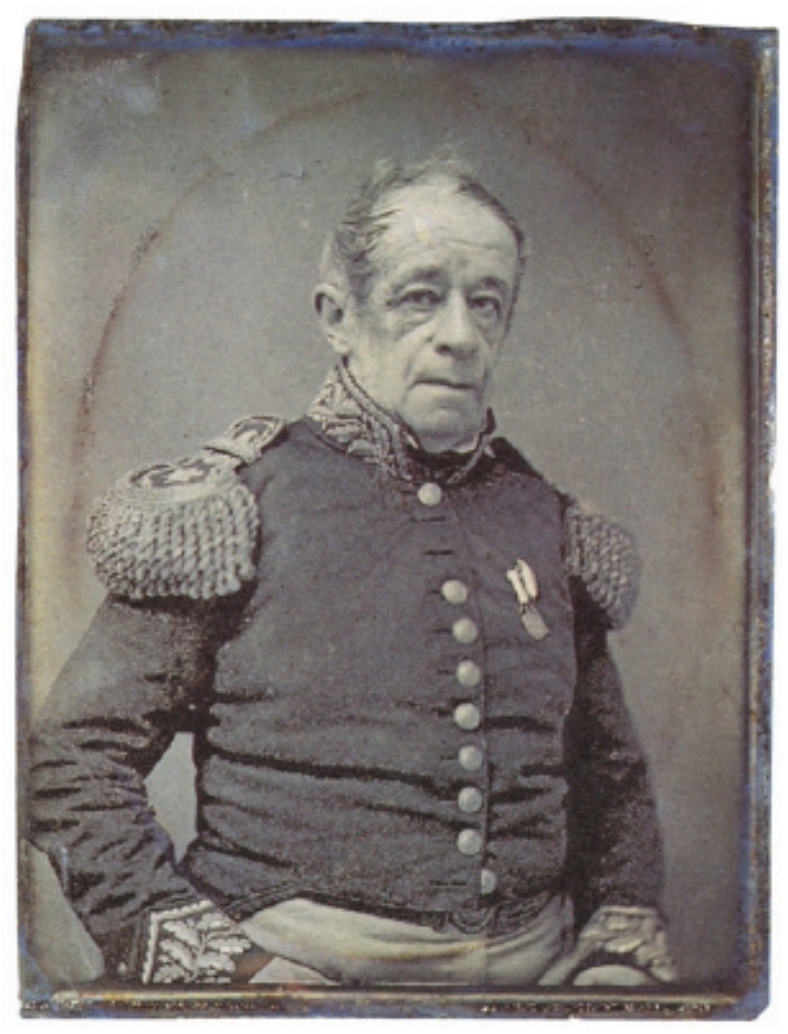

FIGURA 5 - Autor no identificado, General Ignacio Alvarez Thomas, 1853-57, daguerrotipo 13,8 x 10,6 $\mathrm{cm}$. MHN Buenos Aires

Un criterio de valoración estética -rara vez hecho explícito- ha estado siempre presente en la valoración de la "verdad" o "autenticidad" de los retratos aun cuando esto haya sido soslayado tras consideraciones de tipo documental. Los óleos de Gil de Castro fueron considerados "llenos de errores", en la historiografía del arte argentino, cuando en realidad lo que se objetaba en ellos era el estilo. Pero también fueron objeto de valoración estética los retratos fotográficos. Los daguerrotipos que conserva el MHN de aquellos héroes en su vejez rara vez fueron reproducidos como "verdaderas" imágenes de los héroes. Aun cuando esto no se hiciera explícito, aquellas imágenes daguerreanas rara vez fueron funcionales a la construcción de una imagen fidedigna de los próceres. No sólo la edad, sino la contingencia, la "chispa" del azar que brilla en ellos los hacía poco aptos como

${ }^{23}$ Tomás Guido se distinguió por su habilidad como negociador y diplomático desde el momento mismo de la emancipación. Fue Secretario de Guerra y Marina y edecán de José de San Martín, Ministro de Guerra en 1827, ministro plenipotenciario ante la corte de Río de Janeiro en 1828, Ministro de Guerra y Relaciones Exteriores, senador y diputado en diversas ocasiones a lo largo de su vida. 
soporte de la memoria de la gesta revolucionaria. En este sentido, bien cabe comparar los usos pedagógicos de las imágenes de los héroes con la iconografía religiosa. Ellos fueron -son todavía en el ámbito escolar al menos"santos laicos" de la nación. Sus imágenes se construyeron como íconos. No había lugar para el azar ni para el tiempo en ellos.

Buenos Aires, octubre de 2009

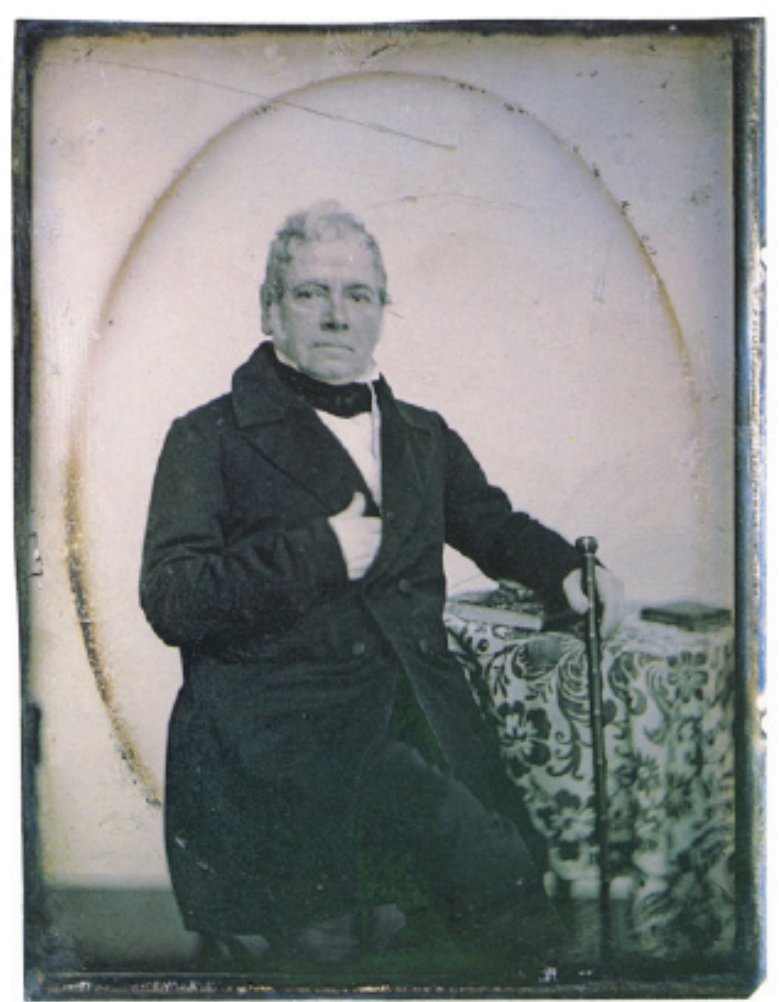

FIGURA 6 - Carlos Pellegrini (atr.) General Tomás Guido, 1854, daguerrotipo 12 × $9 \mathrm{~cm}$. MHN Buenos Aires

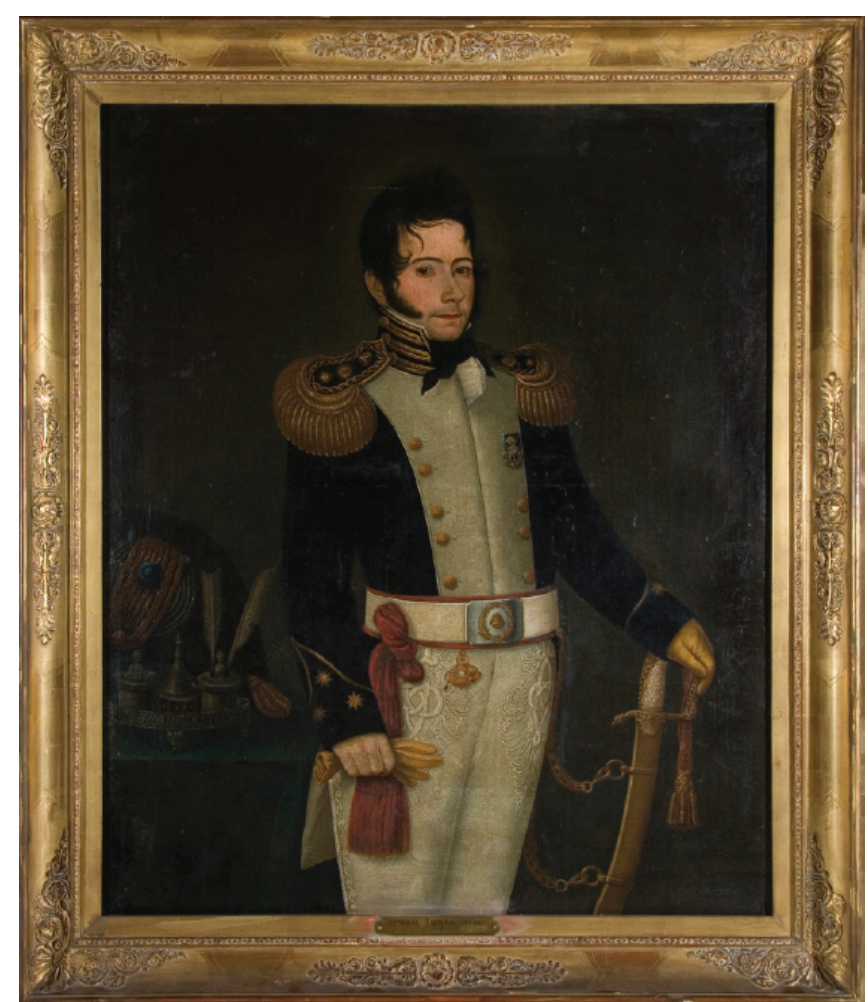

FIGURA 7 - José Gil de Castro, General Tomás Guido, 1819 óleo sobre tela 111,5 x 94 MHN Buenos Aires

\section{Referencias bibliográficas:}

AMIGO, Roberto. Imágenes de la historia y discurso político en el Estado de Buenos Aires (1852-1862) - I. La Galería de los Héroes. In: Arte Argentino de los Siglos XVIII y/o XIX. Menciones especiales Premio Telefónica a la Investigación en Historia de las Artes Plásticas. Buenos Aires: FIAAR, 1998. A.A.V.V. Los años del daguerrotipo. Primeras fotografías argentinas 18431870. Buenos Aires: Fundación Antorchas, 1995.

BATCHEN, Geoffrey. Arder en deseo. La concepción de la fotografía. BarceIona: Gustavo Gili, 2004.

BENJAMIN, Walter. Sobre la fotografía. Edición y traducción de José Muñoz Millanes. Valencia: Pre-Textos, 2004. 
Didi-Huberman, Georges, Ante el tiempo. Historia del arte y anacronismo. Buenos Aires, Adriana Hidalgo, 2006.

ESTOL, Jorge. Pinacoteca virtual sanmartiniana. Buenos Aires: Instituto Nacional Sanmartiniano, 2006.

JORDANOVA, Ludmilla. Defining features. Scientific and medical portraits 16602000. London: Reaktion Books - National Portrait Gallery, 2000.

MARIN, Louis. Des pouvoirs de I'image. Gloses. Paris : Ed. du Seuil, 1993.

MITRE, Bartolomé. Historia de San Martín y de la emancipación sud-americana. Buenos Aires: Imprenta de "La Nación", 1887.

POINTON, Marcia. Hanging the head. Portraiture and Social Formation in Eighteenth-Century England. Yale: Yale University Press, 1993.

QUESADA, Ernesto. El Museo Histórico Nacional y su importancia patriótica -con motivo de la inauguración del nuevo local en el Parque Lezama. Buenos Aires: Kraft, 1897.

Rodríguez Villegas, Hernán. Fotógrafos en Chile durante el siglo XIX. Santiago de Chile: Centro Nacional del Patrimonio Fotográfico, 2001.

SCHARF, Aaron. Art and Photography, London: Penguin Books, 1974.

\section{Title:}

Truth or beauty? Painting, photography, memory, history

\section{Abstract:}

In the framework of an ongoing research on the work of José Gil de Castro (Lima, 1785-1837), an artist who portrayed the American revolutionary leaders (José de San Martín, Simón Bolívar, Bernardo O'Higgins, among others), this essay poses a question on the function and critical literature on the painted portraits of the heroes and protagonists of national histories, before and after the invention of photography. Which ones raise up the collective memory and which do not, how symbolic efficacy is activated and deactivated from different representations of a face through time, are some of the questions raised here.

\section{Keywords:}

Canonic images; photography; memory 